\title{
OCENA KORZYŚCI \\ ORGANIZACYJNO-ZARZĄDCZYCH W TRANSPORCIE LOTNICZYM W WYNIKU ZASTOSOWANIA ANALIZ BENCHMARKINGOWYCH
}

\begin{abstract}
W artykule omówiono kwestię korzyści organizacyjno-zarządczych, jakie są wynikiem wdrożenia benchmarkingu $\mathrm{w}$ linii lotniczej. Aspekt ten ma istotne znaczenie $\mathrm{z}$ dwóch powodów. Po pierwsze, w warunkach rosnącej konkurencji benchmarking stał się bardzo popularny jako metoda wspomagająca tworzenie i podtrzymywanie przewagi konkurencyjnej, stąd weryfikacja korzyści będących efektem jego wprowadzenia ma znaczenie uwierzytelniające. Po drugie, badania odnoszą się do branży lotniczej, w której szanse na pozyskanie lub porównanie danych są bardzo małe, a ewentualnie uzyskane informacje lub wyniki - oryginalne. Warto też nadmienić, że częste i regularne analizy porównawcze pomagają tworzyć konkretne i mierzalne plany krótkoterminowe, które mogą wspierać krok po kroku poprawę wyników. Usprawniają także proces zarządzania poprzez stałe monitorowanie zmian w branży. Benchmarking promuje przede wszystkim „kulturę uczenia się”, tak istotną w perspektywie rozwoju przedsiębiorstwa i efektywnego funkcjonowania. Badania, mające charakter jakościowy, ograniczono do tych pracowników PLL LOT, którzy w zakresie swoich obowiązków realizują zadania określające ofertę i jakość usługi przewozowej jako podstawowej dla tego typu przedsiębiorstw. Większość z badanych potwierdziła pozytywny wpływ metody na jakość usługi przewozowej, natomiast bardziej szczegółowa analiza korzyści uwydatniła te aspekty i obszary przedsiębiorstwa, które są kluczowe nie tylko dla klienta (np. wzrost zadowolenia klientów, poprawa jakości usług) ale i dla efektywnego funkcjonowania linii lotniczej.
\end{abstract}

Słowa kluczowe: zarządzanie, benchmarking, organizacja, linia lotnicza, transport.

\section{WPROWADZENIE}

Współcześnie zarządzanie podlega nieustannym i znaczącym przemianom. Jest więc swoistą ,wędrówką przez chaos" związaną z permanentnym podejmowaniem decyzji i dokonywaniem wyborów. Owo podejmowanie decyzji w ramach zarządzania przedsiębiorstwem może dotyczyć różnych poziomów i płaszczyzn ${ }^{2}$. Wybory z kolei dokonywane są w oparciu o skalę korzyści, jakie z tego tytułu odnotuje dane przedsiębiorstwo. Istotną korzyść mogą przynieść poprawnie wdrożone metody zarządzania, które są nie tylko źródłem wiedzy i cennych informacji, ale i warunkują znacznie większy wybór opcji

\footnotetext{
${ }^{1}$ Dr Beata Gierczak-Korzeniowska, Uniwersytet Rzeszowski, Wydział Wychowania Fizycznego; e-mail: beatagierczak@ur.edu.pl.

${ }^{2}$ M. Wincewicz-Bosy, Miejsce logistyki i tańcucha dostaw $w$ zarzadzaniu przedsiębiorstwem, ZN WSB we Wrocławiu 2013, nr 1(33), s. 178.
} 
postępowania, jako że trudno efektywnie zarządzać organizacją mając tylko jeden scenariusz działań.

Już w latach 70. H. Sherman ${ }^{3}$ stwierdził, że w dorobku nauk o organizacji nie ma bezwzględnie dobrych i bezwzględnie złych wzorców, metod i technik. Należy tylko poznać warunki, w jakich ich zastosowanie przyniesie najbardziej pożądane rezultaty, dlatego przedsiębiorstwa muszą opierać się na wiedzy, posiadać zdolność do samotransformacji oraz być elastyczne i podatne na zmiany, jakie same powinny kreować, a nie tylko na nie reagować. Należy ukształtować przedsiębiorstwo tak, aby było chłonne na innowacje i skłonne postrzegać zmianę jako szansę. Konieczne jest stworzenie systemu uczenia się dla poprawy efektywności i odpowiednie podejście do zagadnień struktury organizacyjnej, obsady stanowisk, kierowania oraz systemu płac, zachęt i nagród ${ }^{4}$. Spore możliwości w powyższych kwestiach stwarza benchmarking, który jako metoda zarządzania umożliwia dostosowanie przedsiębiorstwa do zmian i pilotowanie jego działań w konkurencyjnym środowisku biznesowym ${ }^{5}$. Polega przede wszystkim na uczeniu się jak poprawić działalność organizacji, optymalizując jej procesy i system zarządzania ${ }^{6}$ różnymi sposobami, będąc tym samym źródłem ekwifinalności.

Na procesy decyzyjne oraz sposób zarządzania wpływa sektor oraz branża, w której funkcjonuje organizacja. I tak na przykład dla dotychczasowej polityki i filozofii zarządzania liniami lotniczymi, nie bez znaczenia pozostają procesy liberalizacji światowego lotnictwa ${ }^{7}$ oraz zjawisko globalizacji, które oprócz licznych korzyści ${ }^{8}$ przynosi przewoźnikom lotniczym także i spore wyzwania. Z powodu tych wyzwań, bycie zdolnym do rozwoju i wprowadzania w życie efektywnej strategii jest sprawdzianem dla dobrze zarządzanego przedsiębiorstwa9 ${ }^{9}$. Wiele linii lotniczych do znacznego zainteresowania benchmarkingiem skłoniło pojawienie się na rynku przewoźników niskokosztowych (LCC). Obecne i prężnie rozwijające się linie lotnicze zmuszone zostały do redefinicji swoich celów i wzmożonej aktywności w zakresie działań, mających na celu obniżenie kosztów, przy zachowaniu wysokiej jakości oferowanych usług. I wreszcie czynnikiem oddziałującym na koncepcję i praktykę zarządzania liniami lotniczymi jest nieustanny wzrost poziomu technicznego realizowanych operacji, emulacja w branży oraz konieczność związana z ciągłym dostosowywaniem usług przedsiębiorstwa do zmieniających się i coraz wyższych wymagań klientów.

${ }^{3}$ H. Sherman, It All Depends, A Pragmatic Approach to Organization, Montgomery 1966.

${ }^{4}$ P. Drucker, Innowacja i przedsiębiorczość. Praktyka i zasady, Warszawa 1992, s. 157-164.

${ }^{5}$ M.S. Attiany, Competitive Advantage Through Benchmarking: Field Study of Industrial Companies Listed in Amman Stock Exchange, „Journal of Business Studies Quarterly” 2014, Vol. 5, No. 4, s. 41.

${ }^{6}$ P. Garrod, M. Kinnell, Performance Measurement, Benchmarking and the UK Library and Information Services Sector, „Libri” 2009, Copenhagen, Vol. 46, pp. 141-148.

${ }^{7}$ R. de Arantes, G. Eller, M. Moreira, The main cost-related factors in airlines management,"Journal of Transport Literature" 2014, Vol. 8, No. 1, pp. 8-23, s. 9.

${ }^{8} \mathrm{~Np}$. swobodny dostęp przewoźników do tras i portów lotniczych, swobodę w zakresie ustalania zdolności przewozowej, częstotliwości, rozwijania siatki połączeń i zwiększania liczby połączeń bezpośrednich, ustalania opłat za usługi lotnicze przy zachowaniu zasad konkurencji (W. Rydzkowski, K. Wojewódzka-Król (red.), Transport. Problemy transportu w rozszerzonej UE, PWN, Warszawa 2009, s. 550).

9 A. Shahin, M. Zairi, Strategic Management, Benchmarking and The Balanced Score Card (BSC): An Integrated Methodology, "International Management Journal" 2006, Vol. 2, Issue 2, s. 2. 
Mając świadomość powyższych przesłanek celem artykułu jest próba oceny korzyści organizacyjno-zarządczych, jakie stały się efektem wdrożenia benchmarkingu w analizowanej linii lotniczej. Istotna z punktu widzenia podjętych rozważań wydaje się także opinia pracowników linii, odnosząca się do benchmarkingu i jego wpływu na jakość usług przewozowych PLL LOT.

Zamierzeniem autorki jest ponadto zasygnalizowanie w artykule problemów firm w rozstrzyganiu dylematu dotyczącego wyboru najbardziej korzystnej metody, uwzględniającej zarówno możliwości i kondycję firmy jak i czas, który jest niezbędny do wprowadzenia zaplanowanych zmian. Artykuł powstał na podstawie analizy dostępnych publikacji naukowych oraz badań własnych, które autorka przeprowadziła w PLL LOT.

\section{ANALIZA BENCHMARKINGOWA A DZIAŁALNOŚĆ LINII LOTNICZEJ - KWESTIE TEORETYCZNE I TERMINOLOGICZNE}

Benchmarking ma niezwykle dużą pojemność znaczeniową. W literaturze fachowej z dziedziny zarządzania spotkać można wiele interpretacji tego zagadnienia, tym bardziej że zakres wykorzystania metody do doskonalenia własnej organizacji jest praktycznie nieograniczony. Obejmuje ona swoim zasięgiem wszystkie dziedziny działań podejmowanych w przedsiębiorstwie, począwszy od jakości oferowanych wyrobów, a na zagadnieniach socjalnych kończąc.

Według Prasnikara et al. ${ }^{10}$ benchmarking jest procesem tworzenia wiedzy biznesowej poprzez porównywanie i analizowanie informacji biznesowych o innych firmach w celu poprawy jakości podejmowanych decyzji. W myśl tej definicji celem benchmarkingu jest zastosowanie nowej wiedzy biznesowej do podejmowania decyzji biznesowych, co w rezultacie przekłada się na wyniki działalności przedsiębiorstwa, a w konsekwencji przewagę konkurencyjną. Nacisk na dzielenie się wiedzą w trakcie analizy benchmarkingowej oraz przekazywanie najlepszych praktyk, które tworzą namacalny wkład w rozwój organizacji uczących się, podkreślają również Bhutta i Huq ${ }^{11}$. Nieco inaczej określają benchmarking H. David Sherman i Joe Zhu, którzy uważają, że jest to metoda służąca poprawie funkcjonowania przedsiębiorstwa przez podniesienie dochodów, zwiększenie jakości i ograniczenie kosztów obsługi ${ }^{12}$.

Generalnie rzecz ujmując, benchmarking pozwala na określenie kierunków - wzorców umożliwiających doskonalenie zarządzania organizacjami ${ }^{13}$ gwarantując przetrwanie i utrzymanie przewagi konkurencyjnej zarówno małych, jak i dużych przedsiębiorstw ${ }^{14}$. Dane uzyskane w wyniku procesu benchmarkingu przyczyniają się do:

- identyfikacji mocnych i słabych stron firmy,

10 J. Prasnikar, Z. Debeljak, A. Ahcan, Benchmarking as a tool of strategic management, „Total Quality Management \& Business Excellence" 2005, Vol. 16, No. 2, pp. 257-275.

${ }^{11}$ K.S. Bhutta, F. Huq, Benchmarking - Best Practices: an Integrated Approach, ”Benchmarking: an International Journal" 1999, Vol. 6, No. 3, pp. 256.

${ }^{12}$ H.D. Sherman, J. Zhu, Benchmarking to Seek Lower-Cost High-Quality Service with Data Envelopment Analysis: Evidence from a U.S. bank application, 2006, January, p. 3.

${ }_{13}$ P. Harris, M. Mongiello, Developing a Benchmarking Methodology for the Hotel Industry, 2006

14 A. Kaufmann, F. Tödtling, How Effective is Innovation Support for SMEs? An Analysis of the Region of Upper Austria, „Technovation” 2002, No. 22, http://dx.doi.org/10.1016/S01664972(00)00081-X 
- identyfikacji aktualnej i potencjalnej przewagi komparatywnej w stosunku do innych uczestników komercyjnych operacji biznesowych,

- oceny ryzyka poprzez wykorzystanie alternatywnych linii działania ${ }^{15}$.

Transport lotniczy jest jednym z sektorów gospodarki, w którym benchmarking znajduje coraz większe zastosowanie. „Benchmarking jest najbardziej efektywną drogą wprowadzania najlepszych praktyk w twojej organizacji” oraz „zidentyfikowanie »najlepszego w klasie« rozpoczyna proces biznesowy, który - po wprowadzeniu - doprowadzi przedsiębiorstwo do wyjątkowych osiągnięć"16 - te slogany możemy przeczytać na stronie internetowej Airline Association for Benchmarking and Measurement ${ }^{17}$. W liniach lotniczych benchmarking ma charakter utylitarny, skłania do ciągłego śledzenia i analizowania trendów rynkowych, kształtując tym samym umiejętność pozyskiwania i przetwarzania wiedzy, którą rozwinęli inni.

Przede wszystkim duże możliwości zastosowania metody pojawiają się na poziomie mikroekonomicznym, bowiem w gospodarce rynkowej o sposobach świadczenia usług decydują samodzielnie przedsiębiorstwa transportowe, dla których poszukiwanie wzorców zewnętrznych może być bardzo przydatne.

Istotny wpływ na częstotliwość stosowania benchmarkingu w liniach lotniczych miały narodziny silnych sojuszy strategicznych, które przyczyniły się do rozszerzenia swobody przedsiębiorstw w zakresie kształtowania sieci połączeń, a jednocześnie ułatwiły wymianę informacji i współpracę między liniami w zakresie „dobrych praktyk”. Współpraca w ramach struktur aliansowych obliguje do udziału w realizacji wspólnego przedsięwzięcia, a jego integralną częścią jest dzielenie się wiedzą i posiadanymi środkami z partnerami tak, aby przyniosły one korzyść wszystkim zaangażowanym stronom. Koncepcja benchmarkingu w takim przypadku wpływa na tworzenie nowych pomysłów i lukratywnych rozwiązań mających na celu poprawę istniejącej organizacji, procesów i konkurencyjnych produktów o wysokiej jakości ${ }^{18}$.

Należy jednak zauważyć, że obecnie klasyczne stosowanie benchmarkingu ${ }^{19}$ nie wystarczy. Praktycznie wszystkie sektory - w tym branża lotnicza - podlegają szybkim zmianom strukturalnym z powodu ciągłych zmian technologicznych oraz zmieniających się sił geopolitycznych i ekonomicznych. Tak zwane „dobre praktyki” stosowane dotychczas zostały ukształtowane w czasach większej stabilności, natomiast współcześnie wszelkie narzędzia i najlepsze praktyki muszą być elastyczne oraz dostosowane do szybkich zmian a także niepewnego otoczenia w jakim funkcjonuje przedsiębiorstwo.

Coraz częściej w związku z powyższym mówi się o benchmarkingu przyszłości, który koncentruje się na znalezieniu nowych sposobów pozyskiwania i utrzymania klientów, czyli źródła przychodów. Aby to działało, trzeba zrozumieć, w jaki sposób branża i klien-

${ }^{15}$ L. Marković, V. Dutina, M. Kovačević, Application of benchmarking method in the construction companies, „Facta Universitatis Series: Architecture and Civil Engineering” 2011, Vol. 9, No. 2, pp. 301-314, doi: 10.2298/fuace1102301m, p. 301.

16 http://www.aabm.org (dostęp: 09.10.2013 r.).

17 Zrzeszenie Linii Lotniczych dla Porównań i Pomiaru.

18 J. Babović, C. Raičević, M. Carić, Benchmarking as a function of competitiveness and efficiency in business, „Economics of Agriculture” 2012, No. 1, pp. 115.

${ }^{19}$ Założenia klasycznej analizy porównawczej to m.in.: struktura przemysłu jest przede wszystkim stabilna, najlepsze praktyki można znaleźć tylko u ,graczy rynkowych z historią stałego i stabilnego wzrostu”, najlepiej podejmować tylko te działania, które przyniosą pozytywny i widoczny skutek. 
ci ewoluują. Istotne jest również to jak konkurencja, czyli inne linie lotnicze radzą sobie ze zmianami technologicznymi i społecznymi, a jakie są możliwości naszej firmy w tym zakresie. Benchmarking przyszłości koncentruje się nie tylko na aktualnej sytuacji, ale stanowi mapę drogową udoskonaleń i środków ostrożności na przyszłośćc ${ }^{20}$. Wartość analiz porównawczych jest najskuteczniejsza, gdy jest włączona do strategii organizacyjnej i do wszystkich działań mających na celu poprawę wydajności. Bez zintegrowanej strategii nie będzie jasne, jakie najważniejsze procesy mają być poddane analizie benchmarkingowej ${ }^{21}$.

Benchmarking może stać się więc w liniach lotniczych użytecznym sposobem zarządzania strategicznego, jeśli zostanie wprowadzony integralnie do firmy. Oznacza to, że powinien obejmować wszystkie ważne kategorie działań i obszarów, które są istotne dla efektywnego funkcjonowania linii lotniczej.

\section{BENCHMARKING W ZARZĄDZANIU LINIĄ LOTNICZĄ - OPIS METODOLOGICZNY ORAZ WYNIKI BADAŃ}

Przedsiębiorstwem, w którym przeprowadzono badania były PLL LOT. Analiza wybranych działów tej linii stanowi swoiste case study i chociaż metody case study pozostają kontrowersyjne w podejściu do zbierania danych, są one powszechnie uznawane w wielu badaniach (np. nauk społecznych $)^{22}$. Metoda studium przypadku umożliwia badaczowi uważnie przeanalizować dane w określonym kontekście. W większości przypadków, metoda case study wybiera niewielki obszar geograficzny lub bardzo ograniczoną liczbę osób jako przedmiotów studiów ${ }^{23}$. Stąd badania pierwotne mające charakter jakościowy ograniczono do tych pracowników PLL LOT, którzy w zakresie swoich obowiązków realizują zadania określające ofertę i jakość usługi przewozowej jako podstawowej dla tego typu przedsiębiorstw. Dlatego ważną kwestią był wybór tych działów firmy, które temu kryterium odpowiadały. Wybór - dokonany w sposób celowy - poprzedzony szczegółową analizą struktury i działalności poszczególnych komórek linii lotniczej, doprowadził do wyodrębnienia siedmiu działów, które stanowiły przestrzeń badań. W tabeli 1 wyszczególniono nazwy działów oraz liczbę ich pracowników ${ }^{24}$, których łącznie było 27. Z uwagi jednak na wiarygodność prowadzonych dalej porównań, a także ze względu na podobieństwo pewnych zadań oraz zakresu działań, dokonano podziału owych siedmiu działów na trzy podstawowe grupy, według schematu zamieszczonego również w tabeli 1 . Do tego podziału będą odnosić się wszystkie badania i zależności, jakie wykorzystano dla omówienia tematu niniejszego opracowania.

20 Y. Kazançoğlu, I. Kazançoğlu, Benchmarking service quality performance of airlines in Turkey, Eskişehir Osmangazi Üniversitesi Iibf Dergisi 2013, Nisan 8(1), p. 60.

${ }^{21}$ M.Z. Meybodi, Strategic manufacturing benchmarking, „The TQM Magazine” 2005, Vol. 17, No. 3, pp. 249-258.

${ }^{22}$ Z. Zainal, Case study as a research method, ,Jurnal Kemanusiaan” 2007, bil. 9, Jun., p. 1-6.

${ }^{23}$ Ibidem, s. 2.

${ }^{24}$ Podana nazwa działu oraz liczba ,przebadanych” pracowników odnosi się do okresu, w którym autorka rozdawała kwestionariusze ankietowe (lata: 2012-2014). Jest to kwestia istotna, ponieważ w trakcie jej prawie 4-letniej współpracy z PLL LOT kilkukrotnym zmianom uległy, nie tylko nazwy działów i liczba ich pracowników, ale cała struktura przedsiębiorstwa wraz $\mathrm{z}$ osobą prezesa. 
Tabela 1. Rodzaje działów i liczba ich pracowników poddane badaniom

\begin{tabular}{|c|c|c|c|c|c|}
\hline Dzial & Dział & \multicolumn{2}{|c|}{ Liczebność } & \multicolumn{2}{|c|}{ Procent } \\
\hline aliansów i współpracy międzynarodowej & \multirow{2}{*}{$\begin{array}{c}\text { współpracy } \\
\text { międzynarodowej }\end{array}$} & 4 & \multirow{2}{*}{10} & $15 \%$ & \multirow{2}{*}{$37 \%$} \\
\hline sprzedaży & & 6 & & $22 \%$ & \\
\hline komunikacji marketingowej & \multirow{2}{*}{$\begin{array}{l}\text { marketingu } \\
\text { i produktu }\end{array}$} & 4 & \multirow{2}{*}{10} & $15 \%$ & \multirow{2}{*}{$37 \%$} \\
\hline produktu i standardów obsługi klienta & & 6 & & $22 \%$ & \\
\hline personelu pokładowego & \multirow{3}{*}{$\begin{array}{l}\text { personelu } \\
\text { lotniczego }\end{array}$} & 2 & \multirow{3}{*}{7} & $7 \%$ & \multirow{3}{*}{$26 \%$} \\
\hline doboru i rozwoju personelu & & 3 & & $11 \%$ & \\
\hline obsługi naziemnej & & 2 & & $7 \%$ & \\
\hline
\end{tabular}

Źródło: badania własne.

Powstanie 27-osobowej grupy, stanowiącej wynik celowego doboru próby ${ }^{25}$ do badań, było uwarunkowane kilkoma czynnikami, nie do końca niestety zależnymi od autorki. Po pierwsze - musieli to być pracownicy ww. działów, którzy w zabiegach zmierzających do poprawy jakość usług przewozowych, wykorzystują metodę benchmarkingu. Po drugie niektóre z działów nie były zbyt liczne, co przełożyło się na liczbę kwestionariuszy ankietowych i wreszcie po trzecie - z zupełnie niezrozumiałych względów w niektórych działach to kierownicy lub dyrektorzy decydowali o liczbie kwestionariuszy, jakie wypełnią pracownicy ich działu. Pozytywny wydźwięk całemu zagadnieniu nadaje fakt, że pozwoliło to na przeprowadzenie bardzo wyczerpujących i szczegółowych badań, mających w wielu momentach cechy studiów idiograficznych ${ }^{26}$.

Podstawą oczekiwania korzyści będących efektem wdrożenia każdej metody zarządzania w przedsiębiorstwie jest przede wszystkim jej prawidłowe i poprawne zastosowanie. Aby to miało miejsce niezbędne jest doświadczenie oraz wiedza na temat metody, którą można uzyskać np. w trakcie szkoleń tematycznych. W związku z tym zapytano pracowników PLL LOT o udział w szkoleniach, dotyczących metod zarządzania. Jako że proces uczenia się powinien dotyczyć wszystkich pracowników ${ }^{27}$, w pytaniu uwzględniono przynależność do grupy zawodowej a porównania miedzy nimi dokonano z zastosowaniem testu chi-kwadrat (tabela 2).

Na podstawie badań stwierdzono, że nieco większy odsetek osób z kierownictwa firmy uczestniczył w szkoleniach, jednak różnica pomiędzy obydwiema grupami nie jest na tyle duża, by uznać ją za nieprzypadkową $(p=0,3096)$. Istotny zauważenia wydaje się

${ }^{25}$ Świadomy, uwzględniający określone kryteria dobór jednostek statystycznych, mających być przedmiotem badań. Dobór celowy próby pożądany jest na przykład w każdym przypadku badania skuteczności określonych oddziaływań kierowniczych i decyzyjnych.

${ }^{26}$ Oznaczają prowadzenie pogłębionych badań terenowych na niewielkiej liczbie osób. Każdy przypadek jest opisywany niemal odrębnie, zaś badacz stara się zrozumieć przyczyny zaobserwowanych różnic i podobieństw.

${ }^{27}$ Organizacja ucząca się popiera proces nauki wszystkich pracowników po to, aby sama mogła się ustawicznie zmieniać. Wychodzi się w tym przypadku z założenia, że między pracownikami i kierownikami tworzą się interakcje, tj. procesy wzajemnego oddziaływania na siebie, których skutkiem jest nie tylko przekazywanie wiedzy i informacji, lecz przede wszystkim spowodowanie zmian w postawach współpracujących ze sobą ludzi. 
fakt, że aż 9 z 16 pracowników w ogóle nie uczestniczyło w szkoleniach dotyczących metod zarządzania ${ }^{28}$.

Amerykańskie Centrum Produktywności wskazuje, że benchmarking przyśpiesza procesy poprawy jakości i stałego doskonalenia organizacji ${ }^{29}$, kształtując tym samym pozytywny wizerunek i markę przedsiębiorstwa. Można więc powiedzieć, że benchmarking, bazujący na najlepszych doświadczeniach innych przedsiębiorstw, pozwala wyróżnić się firmie w trwały i najbardziej pożądany przez nią sposób.

Tabela 2. Uczestnictwo w szkoleniach dotyczących metod zarządzania

\begin{tabular}{|c|c|c|c|}
\hline $\begin{array}{c}\text { Uczestnictwo w szkoleniach } \\
\text { dotyczących metod } \\
\text { zarządzania }\end{array}$ & \multicolumn{2}{|c|}{ Grupa zawodowa $(\boldsymbol{p = 0 , 3 0 9 6 )}$} & \multirow{2}{*}{ Razem } \\
\cline { 2 - 3 } & pracownicy & kierownicy & \\
\hline tak & $7(44 \%)$ & $7(64 \%)$ & $14(52 \%)$ \\
\hline nie & $9(56 \%)$ & $4(36 \%)$ & $13(48 \%)$ \\
\hline Razem & 16 & 11 & 27 \\
\hline
\end{tabular}

Źródło: badania własne.

Ten, zdawać by się mogło oczywisty fakt, potwierdzają sukcesy wielu przedsiębiorstw na arenie międzynarodowej i ogólne opinie, z jakimi spotykamy się w literaturze przedmiotu na temat benchmarkingu. Stosunkowo rzadziej jednak możemy znaleźć opinie samych pracowników, które mają bardziej szczegółowy charakter i odnoszą się do konkretnych korzyści w wyniku zastosowania metody, a związanych ze specyfiką danego przedsiębiorstwa. W badaniach przeprowadzonych w PLL LOT uwzględniono zarówno ocenę aspektu jakościowego usług przewozowych, jak i wizerunkowego. Do obu elementów, skądinąd ściśle ze sobą powiązanych odnieśli się pracownicy.

Otóż zdecydowana większość ankietowanych pracowników (23 osoby), zauważa pozytywną rolę benchmarkingu w procesie poprawy jakości usług przewozowych. Dodają oni, że relacje i zależności pomiędzy stosowaniem benchmarkingu a uzyskiwaną jakością są jak najbardziej zauważalne. Tylko 4 pracowników nie potrafi jednoznacznie wypowiedzieć się na temat efektywności metody. Brak natomiast osób, które zakwestionowałyby skuteczność analiz benchmarkingowych i ich znaczenie dla poprawy jakości usług przewozowych (wykres 1).

Wynik ten, będący wyrazem subiektywnych obserwacji i ocen poszczególnych pracowników ma jednak bardzo ogólnikowy charakter - i jak wcześniej wspomniano - nie brakuje podobnych w literaturze przedmiotu.

${ }^{28}$ Inne metody i koncepcje wykorzystywane w PLL LOT to: outsourcing (56\%), zarządzanie jakością (41\%), zarządzanie wiedzą (30\%), zarządzanie strategiczne (26\%), lean management $(11 \%)$, zarządzanie partycypacyjne (11\%), time-based management (4\%).

${ }^{29}$ D. Kisperska-Moroń, Benchmarking jako narzędzie zarządzania logistycznego, Katowice 2000, s. 14. 


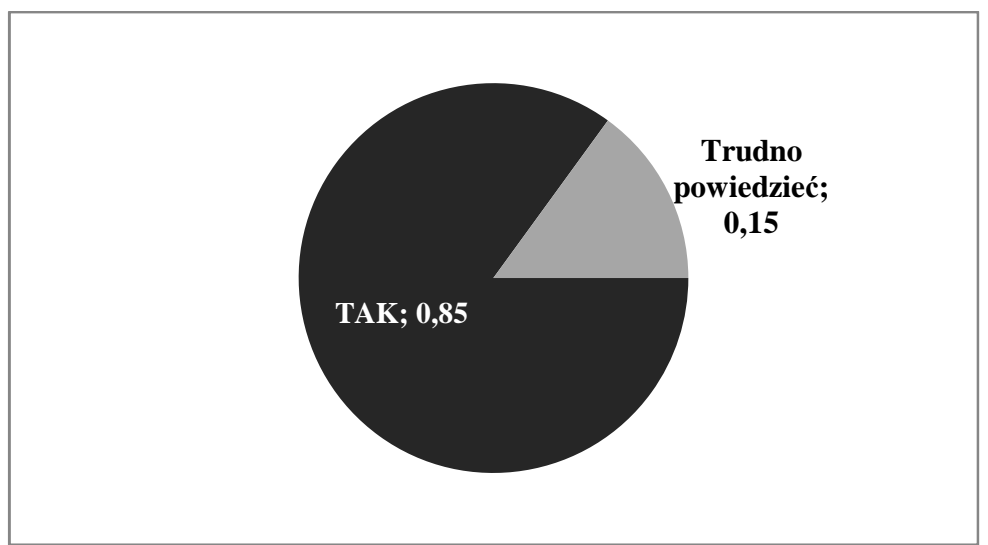

Wykres 1. Wpływ benchmarkingu na jakość usług przewozowych w opinii pracowników PLL LOT Źródło: badania własne.

Dlatego w kolejnym pytaniu poproszono pracowników o ocenę konkretnych korzyści organizacyjnych w wyniku zastosowaniu benchmarkingu, a odnoszących się do specyfiki linii lotniczej (wykres 2). I tutaj oprócz naturalnego zróżnicowania wybranych do badań działów oraz rodzaju zastosowanego benchmarkingu, uwidoczniły się bardziej indywidualne spostrzeżenia.

Za największą korzyść uznano podniesienie jakości oferowanych usług $(78 \%)^{30}$. Jako, że dostarczenie odpowiedniej jakości usługi jest procesem złożonym oraz trudnym i wymagającym dopasowania do oczekiwanej przez klienta wiązki wartości ${ }^{31}$, znaczenie benchmarkingu w tym zakresie zostało szczególnie docenione. Na drugim miejscu znalazło się zwiększenie zadowolenia klientów (70\%), tak ważne dla przedsiębiorstw usługowych, zaś na miejscu trzecim ustalenie pozycji na rynku (68\%). Owo ustalenie pozycji na rynku jest jedyną korzyścią, którą można w jakiś sposób, choć bardzo ograniczony, kojarzyć lub utożsamiać z wizerunkiem PLL LOT, bowiem wśród wszystkich wskazań nie odnotowano innych, na tyle jednoznacznych, które pozwoliłyby odnieść się do wizerunku lub marki firmy. Wśród korzyści wynikających z zastosowania benchmarkingu pracownicy ponadto wskazali: wprowadzenie na rynek nowych produktów/usług $(60 \%)$, ustalenie wewnętrznych standardów $(60 \%)$ oraz zbliżenie do liderów w sektorze $(56 \%)$. Zastanawiać może tylko fakt, że pracownicy nie zauważyli pozytywnego wpływu benchmarkingu na skracanie czasu realizacji poszczególnych procesów lub zadań. W wielu liniach lotniczych od dawna wykorzystuje się benchmarking właśnie w tym celu. Przykładem mogą być linie British Airways, które porównywały, ile czasu potrzebują różne linie lotnicze na rozładunek i ponowny załadunek Boeinga $747^{32}$.

${ }^{30}$ Przy ocenie korzyści brane są pod uwagę i sumowane tylko wskazania: 4 - duże i 5 - bardzo duże.

${ }^{31}$ E. Marciszewska, Jakość w procesie ksztattowania przewag konkurencyjnych na rynku lotniczym [w:] Transport morski i lotniczy w obstudze ruchu pasażerskiego. Implikacje dla regionów, red. A. Panasiuk, M. Pluciński. Wyd. Nauk. US, Szczecin 2008, s. 202.

32 www.boeing.com/commercial/aeromagazine (22.10.2012 r.) Swoje badania prowadził także w 2005 roku Boeing. Miały one na celu wyjaśnienie klientom linii lotniczych, kosztów ich 
Powyższe wskazania obrazują najbardziej istotne dla pracowników aspekty funkcjonowania firmy, czyli jakość usług i zadowolenie klienta. J. Juran uważał, że dzięki skupianiu się na rzeczywistych potrzebach klientów, menedżerowie i robotnicy mogą poświęcać swoje wysiłki na to, co jest naprawdę ważne ${ }^{33}$ i co przynosi największe zyski w długoletniej perspektywie. Ma to tym większe znaczenie, że w obecnym przemyśle lotniczym, charakteryzującym się bardzo niewielkimi przewagami, linie lotnicze muszą dokładać wszelkich starań w sferze zarządzania aby sprostać wymaganiom klientów i utrzymać się na rynku ${ }^{34}$.

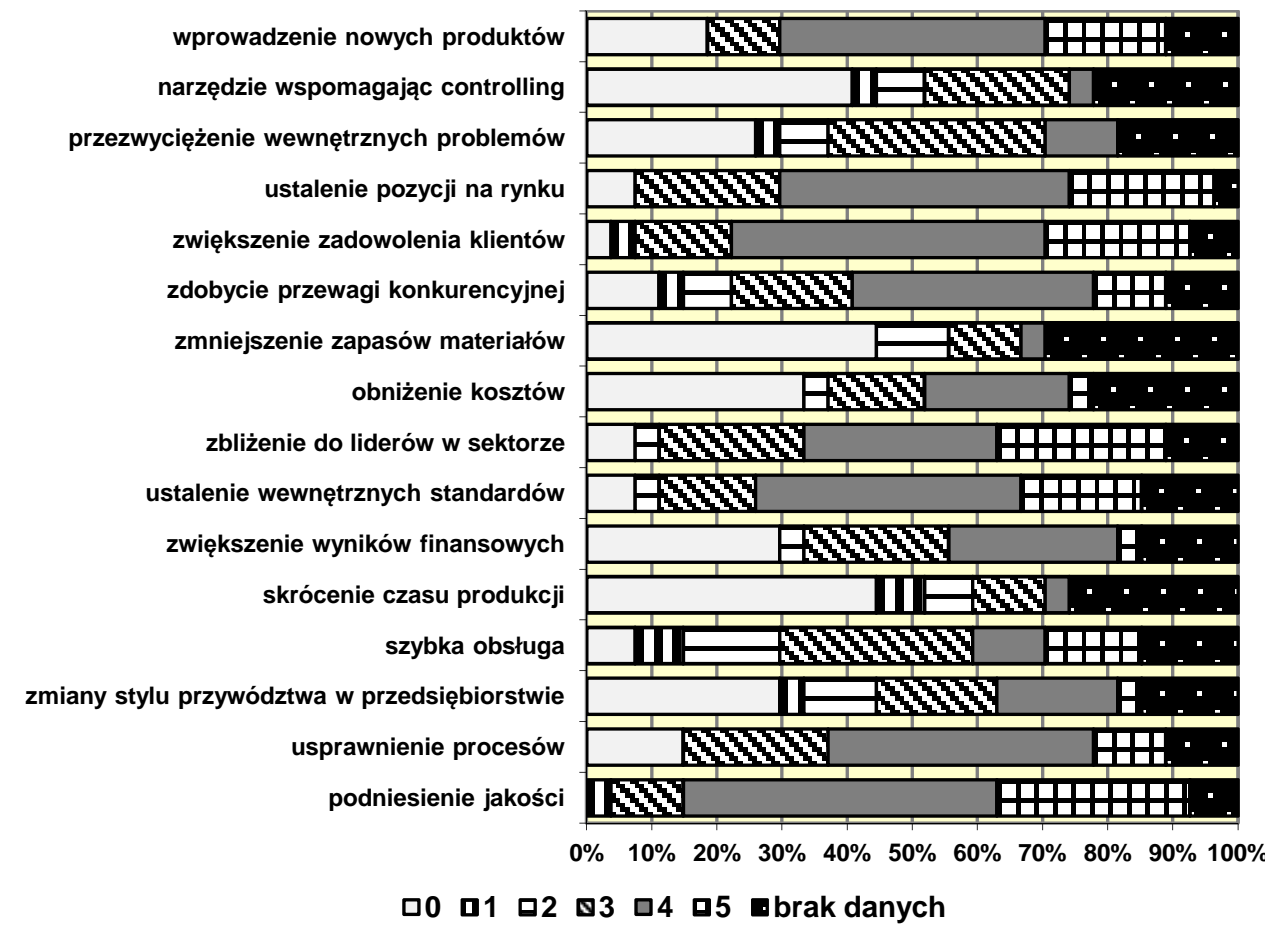

Wykres 2. Ocena konkretnych korzyści dla PLL LOT w wyniku zastosowania benchmarkingu w opinii pracowników. Zaproponowana w badaniu skala: 0 - brak, 1 - bardzo małe, 2 - małe, 3 - przeciętne, 4 - duże, 5 - bardzo duże

Źródło: badania własne.

utrzymania a także czynników, które doprowadzają do wysokich nakładów. Celem badań było także dostarczanie liniom lotniczym rozwiązań i najlepszych praktyk, które pomogłyby im ulepszać ich funkcjonowanie, optymalizować koszty utrzymania i zwiększać zyskowność.

33 J. Stoner, E.R. Freeman, R.D. Gilbert, Kierowanie, PWE, Warszawa 2001, s. 227.

${ }^{34}$ International Airline Benchmarking Study - Summary of Findings, "Ethos Consultancy" 2010, January 31, p. 2. 
Konkludując, uzyskane wyniki mimo swojej oryginalności odnoszą się do jednej, konkretnej linii lotniczej/branży i należy mieć na uwadze, że zapewniają bardzo małą podstawę uogólnienia naukowego z powodu „użycia” niewielkiej liczby respondentów i jednego opisanego zdarzenia ${ }^{35}$.

\section{PODSUMOWANIE}

Każda linia lotnicza (bez względu na wielkość) stanowi złożony system, w skład którego wchodzą zasoby rzeczowe, ludzkie, finansowe i informacyjne. Poprzez sprawne i umiejętne zarządzanie, system ten generuje wartość dla przedsiębiorstwa i jego klientów. Cechuje go także większa pewność i swoboda działania w turbulentnym otoczeniu. Aby to jednak miało miejsce przedsiębiorcy muszą stale dokonywać wyboru spośród wielu metod i koncepcji zarządzania, które co jakiś czas wzbudzają ogólne zainteresowanie.

Jedną z takich metod jest benchmarking, który pozwala decydentom zrozumieć, ile należy jeszcze zmienić aby dorównać najlepszym. Częste i regularne analizy porównawcze pomagają tworzyć konkretne i mierzalne plany krótkoterminowe, które mogą wspierać krok po kroku poprawę wyników. Usprawniają także proces zarządzania poprzez stałe monitorowanie zmian w branży. Benchmarking promuje przede wszystkim „kulturę uczenia się", tak istotną w perspektywie rozwoju przedsiębiorstwa i efektywnego funkcjonowania.

W niniejszym artykule przedstawiono i opisano korzyści, jakie zidentyfikowali pracownicy PLL LOT po wdrożeniu benchmarkingu. Wskazane przez nich osiągnięcia odnoszą się głównie do obszarów, które mają kluczowe znaczenie dla prawidłowego funkcjonowania przedsiębiorstwa transportowego. Należy jednak mieć na względzie, że przedsiębiorstwa w branży się różnią i efekty wdrożenia tej samej metody zarządzania mogą być zupełnie inne. Dlatego tak dużego znaczenia nabiera świadomy wybór nie tylko sposobu czy metody usprawnienia organizacji ale i wiedza o kondycji i możliwościach naszego przedsiębiorstwa.

\section{LITERATURA}

[1] Attiany M.S., Competitive Advantage Through Benchmarking: Field Study of Industrial Companies Listed in Amman Stock Exchange, „Journal of Business Studies Quarterly” 2014, Vol. 5, No. 4.

[2] Babović J., Raičević V., Carić M., Benchmarking as a function of competitiveness and efficiency in business, ,Economics of Agriculture” 2012, No. 1, pp. 115-127.

[3] Bhutta K.S., Huq F., Benchmarking - Best Practices: an Integrated Approach, "Benchmarking: an International Journal" 1999, Vol. 6, No. 3, pp. 254 -268.

[4] Bolesta-Kukułka K., Jak patrzeć na świat organizacji, PWN, Warszawa 1993, s. 189.

[5] De Arantes R., Eller G., Moreira M., The main cost-related factors in airlines management,'Journal of Transport Literature" 2014, Vol. 8, No. 1, pp. 8-23.

[6] Drucker P., Innowacja i przedsiębiorczość. Praktyka i zasady, PWN, Warszawa 1992.

[7] Drucker P., Zarządzanie w czasach burzliwych, Wyd. AE w Krakowie, Kraków 1995. 35 Yin R.K., Case Study Research: Design and Methods. Beverly Hills 1984, Calif: Sage Publica-
tions, p. 21. 
[8] Garrod P., Kinnell M., Performance Measurement, Benchmarking and the UK Library and Information Services Sector, „Libri” 2009, Copenhagen, Vol. 46, pp. 141-149.

[9] Harris P., Mongiello M., Developing a Benchmarking Methodology for the Hotel Industry, 2006.

[10] International Airline Benchmarking Study - Summary of Findings, "Ethos Consultancy" 2010, January 31.

[11] Kaufmann A., Tödtling F., How Effective is Innovation Support for SMEs? An Analysis of the Region of Upper Austria, „Technovation” 2002, No. 22, http://dx.doi.org/ 10.1016/S0166-4972(00)00081-X.

[12] Kazançoğlu Y., Kazançoğlu I., Benchmarking service quality performance of airlines in Turkey, Eskişehir Osmangazi Üniversitesi libf Dergisi 2013, Nisan 8(1), pp. 59-91.

[13] Kisperska-Moroń D., Benchmarking jako narzędzie zarządzania logistycznego, Wyd. AE Katowice, Katowice 2000.

[14] Marciszewska E., Jakość w procesie ksztattowania przewag konkurencyjnych na rynku lotniczym [w:] Transport morski i lotniczy $w$ obstudze ruchu pasażerskiego. Implikacje dla regionów, red. A. Panasiuk, M. Pluciński. Wyd. Nauk. US, Szczecin 2008.

[15] Marković L., Dutina V., Kovačević M., Application of benchmarking method in the construction companies, „Facta Universitatis Series: Architecture and Civil Engineering” 2011, Vol. 9, No. 2, pp. 301-314, doi: 10.2298/fuace1102301m.

[16] Meybodi M.Z., Strategic manufacturing benchmarking, „The TQM Magazine” 2005, Vol. 17, No. 3, pp. 249-258.

[17] Prasnikar J., Debeljak Z., Ahcan A., Benchmarking as a tool of strategic management, „Total Quality Management \& Business Excellence” 2005, Vol. 16, No. 2, pp. 257-275.

[18] Rydzkowski W., Wojewódzka-Król K. (red.), Transport. Problemy transportu $w$ rozszerzonej UE, PWN, Warszawa 2009.

[19] Shahin A., Zairi M., Strategic Management, Benchmarking and The Balanced Score Card (BSC): An Integrated Methodology, "International Management Journal" 2006, Vol. 2, Issue 2.

[20] Sherman H., It All Depends, A Pragmatic Approach to Organization, Montgomery 1966.

[21] Sherman H.D., Zhu J., Benchmarking to Seek Lower-Cost High-Quality Service with Data Envelopment Analysis: Evidence from a U.S. bank application, 2006, January.

[22] Stoner J., Freeman E.R., Gilbert R.D., Kierowanie, PWE, Warszawa 2001.

[23] Wincewicz-Bosy M., Miejsce logistyki $i$ tańcucha dostaw $w$ zarzadzaniu przedsiębiorstwem, ZN WSB we Wrocławiu 2013, nr 1(33), s. 178.

[24] Yin R.K., Case Study Research: Design and Methods. Beverly Hills 1984, Calif: Sage Publications.

[25] Zainal Z., Case study as a research method, „Jurnal Kemanusiaan” 2007, bil. 9, Jun.

\section{THE EVALUATION OF ORGANIZATIONAL AND MANAGEMENT BENEFITS IN AIR TRANSPORT AS A RESULT OF THE APPLICATION OF BENCHMARKING ANALYSES}

This paper discusses organizational and management benefits which result from the implementation of benchmarking in an airline. This aspect is important for two reasons. First of all, under the conditions of growing competition, benchmarking has become very popular as a means of supporting the creation and maintenance of competitive advantage, 
hence the verification of the benefits resulting from its introduction is credible. Secondly, the research relates to the aviation industry, where the chances of acquiring or comparing data are very small and information or results which are possibly obtained are original. It is also worth mentioning that frequent and regular comparative analyses help create specific and measurable short-term plans which can support gradual improvement in the results. They also improve the management process by constantly monitoring changes in the industry. Benchmarking primarily promotes a 'learning culture' which is extremely important for enterprise development and its effective functioning. The qualitative research was limited to these PLL LOT employees who are responsible for carrying out tasks which define the offer and quality of a transport service as the basic service for this type of enterprise. Most of the respondents confirmed the positive impact of this method on the quality of a transport service, while a more detailed analysis of its benefits highlighted those aspects and areas of the company which are crucial, not only for the customer (e.g. improving customer satisfaction and the quality of services), but also for the efficient operation of the airline.

Keywords: management, benchmarking, organization, airline, transport.

DOI: 10.7862/rz.2017.mmr.25

Tekst złożono $w$ redakcji: wrzesień 2017 r.

Przyjęto do druku: grudzień 2017 r. 